\title{
反射引張応力波によるモルタル材の衝撃引張 強度測定と評価法の検討
}

\author{
臺丸谷 政 志* 小林 秀 敏* 志 澤 秀 康**
}

Estimation of Impact Tensile Strength of Mortar Using Reflected Tensile Stress Waves

by

\author{
Masashi Daimaruya * , Hidetoshi Kobayashi * and Hideyasu Shizawa **
}

Impact tensile strength of concrete (mortar) and its measuring method is discussed. The experiment is conducted by means of a Hopkinson bar technique using an air-gun arrangement. The measuring method is based on the superposition and concentration of tensile stress waves reflected both from the free ends of a striking bar and a specimen bar. The impact tensile experiment of mortar specimen bars was performed as well as static strength tests. The experimental data in relation to those strengths were analyzed statistically by a Weibull distribution. The impact tensile strength was significantly influenced by loading rates, and it was found to be about 1.5 times of the static value. For examining the adequacy of the present measuring method, numerical simulations on the stress waves propagated in the specimen bars were carried out under the condition of two-dimensional axisymmetric model using the FEM code and some reasonable results were found.

Key words : Impact test, Impact tensile strength, Concentration of tensile stress waves, Mortar, Cumulative fracture probability, Strain rate, Numerical simulation

\section{1 緒言}

コンクリート材料は, 主として圧縮強度部材として使 用され，試験方法が簡単であるだけではなくコンクリー 卜のさまざまな物性が定性的に圧縮強度と関係している 等の理由で, 破壊強度に関しては静的圧縮強度を中心と

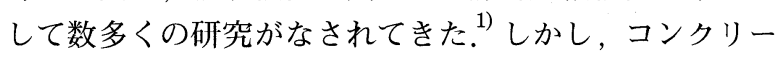
卜材に関しても引張り強度の重要性が増して抢り種々の 研究が報告されている. ${ }^{2)}$ 特に, 衝撃的に荷重が作用する とき，それが圧縮負荷であっても応力波の反射・干渉の 結果, 引張り応力波が伝ぱし引張り応力領域が生じる場

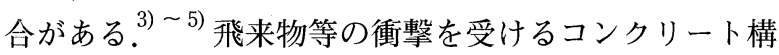
造物，落石覆工や激震時のコンクリート建造物を想定す れば, (6) -9) コンクリートの衝撃荷重下における引張り強 度を含めた力学的特性を知ることは重要である.

セラミックス，コンクリートやモルタル等の塑性的変 形をほとんど伴わないぜい性材料の引張り強度を直接的 に測定することは, 試験片支持部の破壊や曲げモーメン 卜成分の影響もあり極めて困難である.引張り強度に関 しては, 静的強度であってもコンクリート材の場合, 直 接引張り試験法は確立されておらず，多くは間接引張り 試験法である割裂試験に依っている. ${ }^{10)}$ 一方, 衝撃引張 り荷重下に打けるコンクリート材の衝撃強度試験に関し て，例えば，コンクリート試験片の両端を試験装置治具 に接着保持した直接衝撃引張り実験, ${ }^{11)}$ ～13) 割裂試験法 を衝撃荷重の場合に応用した衝撃割裂試験 ${ }^{11), 14)}$ 等の試 みがある。また，一般に高速負荷の下での材料の動的変
形強度はスプリット・ホプキンソン棒法を用いて測定さ れることが多いが ${ }^{15)}$ ホプキンソン棒法によるカラーを用 いた反射波による引張り試験 ${ }^{16), 17)}$ においても試験片支 持方法の問題が依然として残り，ぜい性材料であるコン クリートおよびモルタル材に対して直接適用することは 難しいと思われる。いずれにしても, 未だコンクリート 材料の衝撃引張り強度試験法は確立されていない.

本論文では，著者らが先に提案したぜい性材料に対 する簡便な衝撃引張り試験法である反射引張り応力波 法 $^{18)}$ ２2) を粗骨材を含まないコンクリート材すなわちモ ルタル材に適用した場合について検討を行った，反射引 張り応力波法は 1 次元応力波の入反射による引張り応力 波の重ね合わせを利用しており，実験はエアー・ガン装 置を用いて行った。本試験法では，試験片両端をつかみ 支持あるいは接着固定をする必要がなく，棒状試験片の 一端を入力伝達棒に密着させ他端を自由端とする。試験 片の自由端で反射した引張応力波と衝撃棒の自由端から の反射引張応力波が，試験片中の一点で重ね合わされそ の位置を中心として引張り応力領域が進展し, 試験片が 引張り破断される. 入力伝達棒および試験片に接着した ひずみゲージより引張り破断応力を測定し， ワイブル分 布を用いて統計的評価を行った．測定理論上，ひずみ速 度を直接求めることは難しいが測定波形から破断時間を 推定しひずみ速度を算定した。 また，本試験法の妥当性 を検証するため, FEM コードを用いて 2 次元軸対称応 力波動解析を行い，モルタル試験片中の応力波の伝ぱ挙

$\dagger \quad$ 原稿受理 平成 12 年 6 月 9 日 Received June 9,2000

* 正 会員 室蘭工業大学工学部機械システム工学科 †050-8585 室蘭市水元町, Dept. of Mech. Sys. Eng., Muroran Inst. of Tech., Mizumoto-cho, Muroran, 050-8585

** 室蘭工業大学大学院 ＝050-8585 室蘭市水元町, Graduate Student, Muroran Inst. of Tech., Mizumoto-cho, Muroran, 050-8585 
動に関する検討を行った。

\section{2 反射引張り応力波法}

\section{$2 \cdot 1$ 測定理論}

本実験法である反射引張り応力波法は, 1 次元応力波 の入反射・重ね合わせを利用しており，その測定理論の 模式図を Fig. 1 に示す. 棒 I は衝撃棒, 棒 II は入力伝 達棒，棒亚は試験片棒である。模式図は，軸心が一致し 密着されている入力伝達棒 II と試験片棒四に, 衝撃棒 I が軸方向に衝突したときの応力波伝ぱを表している.

本実験法では, (i) 衝撃棒, 入力伝達棒および試験片 棒に関して 1 次元応力波の入反射による重ね合わせがで き, (ii) 試験片棒の圧縮強度／引張り強度の比が大で, 試験材は圧縮応力波の履歴影響を受けずかつ破断に至る まで弾性的に挙動すると仮定する.

衝撃棒 I が入力伝達棒 II に衝突するとき衝突面に発生 した圧縮応力波 $\sigma$ は棒 I 扣よび棒 II 中をそれぞれ逆方向 に伝ぱする. 入力伝達棒 II を伝ぱする圧縮応力波は試験 片棒 III との接触面に到り， $\sigma$ の一部 $\beta \sigma$ が棒四へ透過し， $\alpha \sigma$ は反射引張り波として棒 II 中を左方に伝ぱする.こ こで $\alpha$ および $\beta$ は反射率および入射率であり, 詳細は後 述する. 試験片棒正へ透過した圧縮応力波 $\beta \sigma$ は, 自由 端で反射され反射引張り応力波 $\beta \sigma$ となり試験片棒吕中 を左方に伝ぱする。一方，衝撃棒 I 中を左方に伝ぱする

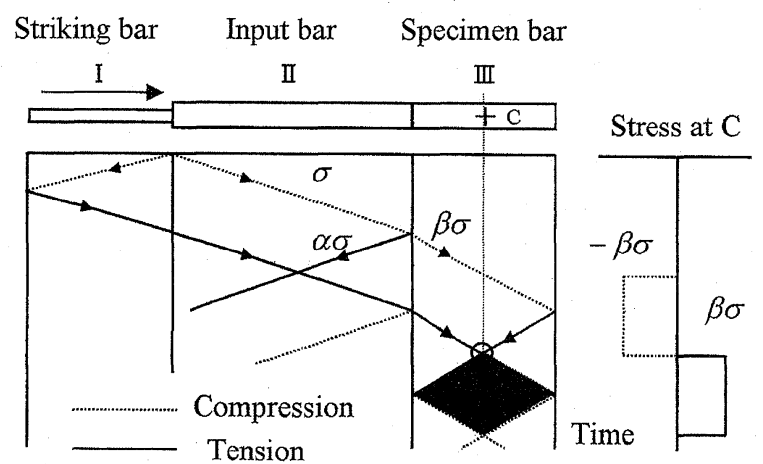

Fig. 1. Stress wave propagation and concentration of tensile stress waves in a specimen.
圧縮応力波は自由端で反射し引張り応力波となって右方 に伝ぱし入力伝達棒 IIに透過する。この引張り応力波 $\sigma$

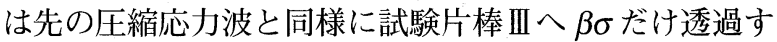
る.これら二つの引張り応力波は試験片棒 III $C$ 点で重 なり引張り応力波の集中が生じ, 引張り応力領域が図中 の影部で示した位置一時間域において進展する. 断面 $C$ は最初の引張り応力波集中位置であり, かつその持続時 間も最大になる. 断面 $C$ に打ける応力変動を図中右側に 示す．ぜい性材料である試験片棒吕が断面 $C$ 近傍で引張 り破断するとき，この引張り応力値を衝撃引張り強度と 定義する。

\section{$2 \cdot 2$ 実験装置および方法}

本実験はエアー・ガン装置 ${ }^{20)}$ を用いて行った。Fig 2 に示すように，エアー・ガンより打ち出された衝撃棒は 入力伝達棒に衝突し, 衝突端で発生した圧縮応力波は入 力伝達棒を伝ぱし共軸上に密着して置かれた試験片棒に 透過する. 衝撃棒と入力伝達棒の衝突により発生する衝 撃力の大きさと持続時間は, 衝撃棒の衝突速度と長さに よって決められる，供試モルタル材（直径 $50 \mathrm{~mm}$, 長さ $750 \mathrm{~mm}$ ）の中央近傍が引張り応力波の集中開始位置にな るように, 衝撃棒には直径 $20 \mathrm{~mm}$ ，長さ $540 \mathrm{~mm}$ のステ ンレス (SUS306) 丸棒を, 入力伝達棒には直径 $50 \mathrm{~mm}$, 長さ $1500 \mathrm{~mm}$ の一般構造用圧延鋼材 (SS400) 丸棒を用い て実験を行った，入力伝達棒には試験片接触面より $6 \mathrm{~d}$, 12d（d：入力伝達棒および試験片棒の直径）の位置に半 導体ひずみゲージが 2 枚軸対称に接着されており, 衝撃 棒から入力伝達棒への入射応力と試験片端からの反射波 が検出され，入力伝達棒から試験片棒への入射応力が 2 点ひずみゲージ法 ${ }^{18)}$ によって算定される。 また，試験片 棒にも両端より $5 \mathrm{~d}(250 \mathrm{~mm})$ の 2 ケ所にそれぞれひずみ ゲージを 2 枚軸対称に接着し試験片内の応力波の伝ぱ挙 動を直接観測した。

\section{3 モルタル試験材料}

\section{$3 \cdot 1$ 配合比および寸法}

試験材料には粗骨材を含まないコンクリートすなわち モルタル材を使用した，重量配合比を Table I に示す.

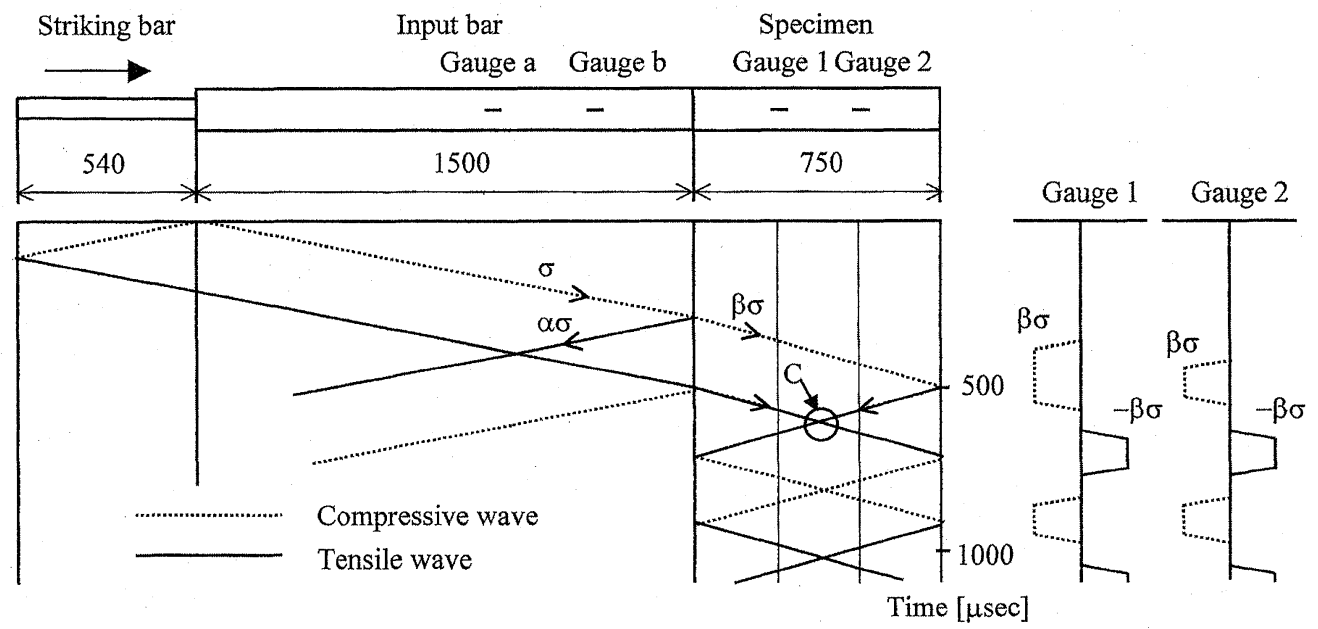

Fig. 2. Main arrangement in the present experiment. 
Table I . Mix proportions of mortar for a cubic meter.

\begin{tabular}{|c|c|}
\hline Water/cement ratio & 0.55 \\
Fine aggregate content & $60 \%$ \\
Air content & $4.5 \%$ \\
\hline Portland cement & $418 \mathrm{kgf}$ \\
Water & $230 \mathrm{kgf}$ \\
Fine aggregate & $1,583 \mathrm{kgf}$ \\
Coarse aggregate & - \\
Water-reducing admixture & $0.836 \mathrm{kgf}$ \\
\hline Total weight per cubic meter & $2,231 \mathrm{kgf}$ \\
\hline
\end{tabular}

セメントは普通ポルトランド・セメントを使用し，細骨 材の粒径は $5 \mathrm{~mm}$ 以下とした。モルタル試験材は直径 $50 \mathrm{~mm}$ ，長さ $750 \mathrm{~mm}$ の円柱試験片で，材歯令 90 日のもの を用いた。

\section{$3 \cdot 2$ 静的試験}

先ず，供試モルタル材の静的な機械的性質を得るため に，静的間接引張り試験（割裂試験），三点曲げ試験お よび圧縮試験を行った。曲げ試験ではスパンを $700 \mathrm{~mm}$ とし，割裂試験および圧縮試験には長さ $100 \mathrm{~mm}$ に切り 出した短円柱試験片を用いた。

引張り試験には，直接に引張り強度を求める直接引張 り試験と間接的に引張り強度を求める間接引張り試験 （割裂試験）の方法がある．間接引張り試験はJISA1113 「コンクリートの引張強度試験方法」規格によって制定さ れているが，直接引張り試験に関しては標準試験法は規 定されていない. ${ }^{10)}$ 割裂試験，三点曲げ試験および圧縮試 験はともに万能試験機 (INSTRON, model 5586) クロス ヘッド変位速度 $0.5 \mathrm{~mm} / \mathrm{min}$ で行った。 これらの試験か ら得られた供試モルタル材の機械的性質を Table II に示 す。ここで, $E$ は縦弾性係数, $\rho$ は密度, $v$ はポアソン 比， $\sigma_{t s}$ は間接引張り強さ， $\sigma_{b}$ は曲け強さ， $\sigma_{c}$ は圧縮強 さである。なお， $c_{0}$ は波動伝ば実験より得られた 1 次元 応力波の伝ぱ速度である。

\section{4 反射応力波法による衝撃引張り試験}

\section{$4 \cdot 1$ 引張り応力領域進展と破断}

前述の Fig. 2 は本実験における応力波伝ぱの模式図と 試験片のひずみゲージ位置における予測される時間変動 を示している。モルタル試験片棒の断面 $C$ は最初の引張 り応力波集中位置でありかつその持続時間も最大になる. この断面を中心として引張り応力領域が左右に進展して ゆく．したがって断面 $C$ 付近に打ける引張り破断が予測 される。ここで， $\sigma$ は入力伝達棒からの圧縮応力波で,

Table II . Mechanical properties of mortar.

\begin{tabular}{|l|r|}
\hline Static splitting tensile strength $: \sigma_{\mathrm{ts}}$ & $3.6 \mathrm{MPa}$ \\
Static bending strength $: \sigma_{\mathrm{b}}$ & $6.4 \mathrm{MPa}$ \\
Static compressive strength $: \sigma_{\mathrm{c}}$ & $30.5 \mathrm{MPa}$ \\
Elastic modulus : E & $28.7 \mathrm{GPa}$ \\
Mass density : $\rho$ & $2251 \mathrm{~kg} / \mathrm{m}^{3}$ \\
Poisson's ratio $: v$ & 0.2 \\
\hline Velocity of stress wave $: \mathrm{c}_{0}$ & $3571 \mathrm{~m} / \mathrm{sec}$ \\
\hline
\end{tabular}

入力伝達棒とモルタル試験片棒の接触境界における反射 率 $\alpha$ と透過率 $\beta$ は次式で与えられる.

$$
\alpha=\frac{A_{2} E_{2} c_{01}-A_{1} E_{1} c_{02}}{A_{2} E_{2} c_{01}+A_{1} E_{1} c_{02}}, \beta=\frac{2 A_{1} E_{2} c_{01}}{A_{2} E_{2} c_{01}+A_{1} E_{1} c_{02}}
$$

ここで, $A$ は断面積, 添字 1,2 はそれぞれ入力伝達棒, 試験片棒を表わしている。本実験では， $A_{1}=A_{2}=7850$ $\mathrm{mm}^{2}, E_{1}=210 \mathrm{GPa}, E_{2}=31 \mathrm{GPa}, c_{01}=5170 \mathrm{~m} / \mathrm{s}, c_{02}=$ $3570 \mathrm{~m} / \mathrm{s}$ であり, $\alpha=-0.67, \beta=0.33$ が得られる.

Fig. 3 に試験片上のひずみゲージから検出された応答 波形を示す．すなわち，試験片の衝撃入力端より $150 \mathrm{~mm}$ (Gauge1) と 600mm (Gauge2) の位置における応力変動 を示したものである，正值は引張り応力，負值は圧縮応 力を表す。(a) は試験片に破断が生じなかったときに得 られた応答の一例であり，大きな分散を示さず $5 \mathrm{MPa}$ 強 の圧縮および引張り応力が試験片内を往復しているのが 読み取れる。(b) は試験片に破断が生じたときに得られ たゲージ応答の一例である. 1 回の引張り応力波が通過 した後にゲージ応答波形に乱れが生じており，この時点 までに引張り破断が生じたものと推定される.

Fig. 4 に衝撃引張り破断したモルタル試験片の例を示 す。最初に引張り応力が生じる中央付近で破断している ことがわかる．他の試験片についても総て棒中央付近で 破断した。

Fig. 5 は, Fig. 3(a) に示す応力の時間変動をモルタル 試験片を伝ぱする応力波形に描き直した図で，中央断面 $C$ 付近を中心として引張り応力領域が発達してゆく様子 がわかる。

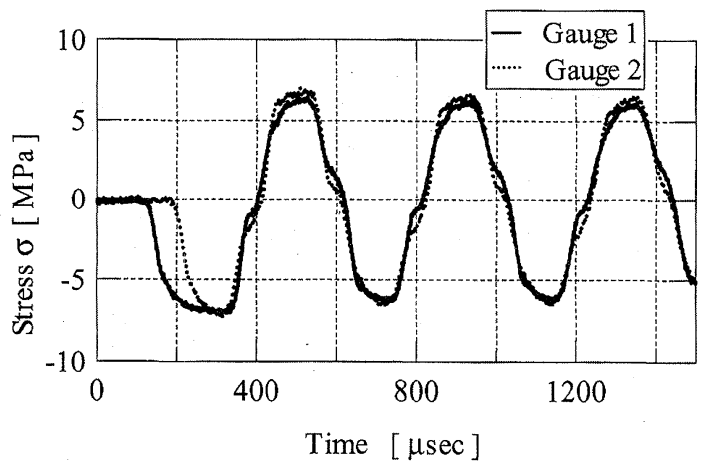

(a) Case of no visual break

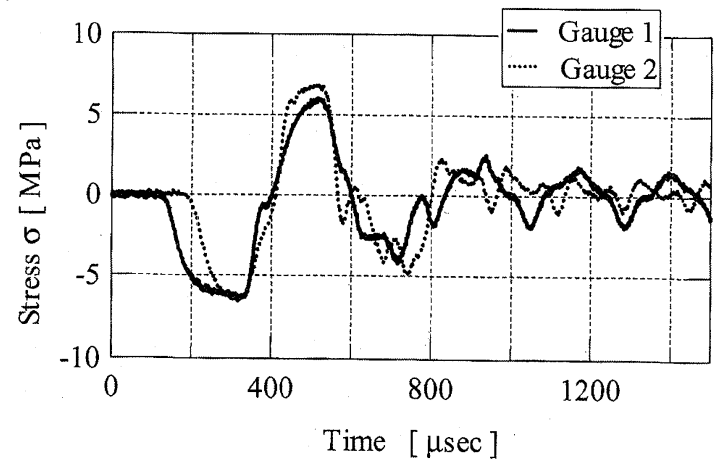

(b) Case of break

Fig. 3. Variations of stress at gauge locations 1 and 2 of mortar specimens. 


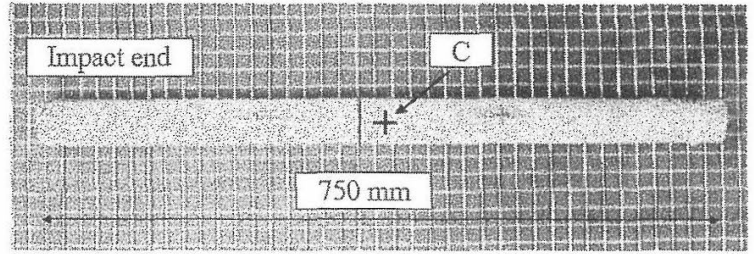

Fig. 4. Broken mortar specimen.
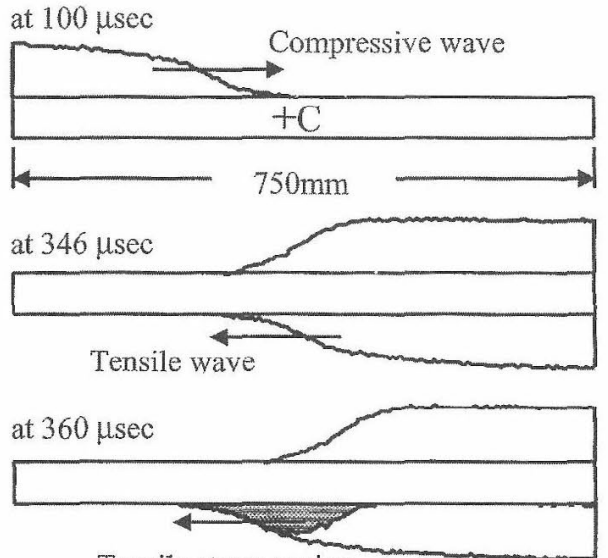

Tensile stress region
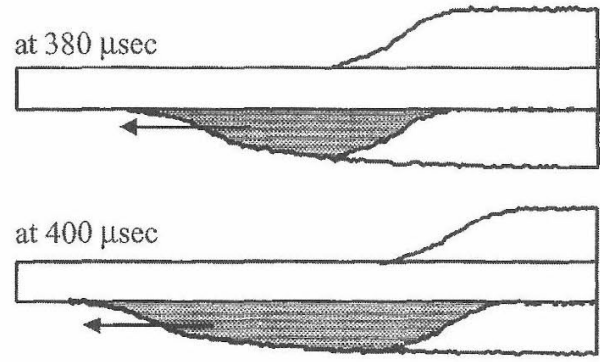

Fig. 5. Development of tensile stress region.

\section{$4 \cdot 2$ 衝撃引張り強度}

コンクリート材は比較的強度值のばらつきが大きい材 料であるため，七ラミックス強度評価の場合によく用い られているように, ワイブル分布を用いて統計的に俨価 した。静的強度試験および衝撃引張り試験より得られた 供試モルタルの破壊強さのワイブル分布をFig. 6 に示 す。累積破壞確率 Fi はメディアン・ランク法を用いて定 めた。各試験結果について, 最小二乗法を用いて回帰直 線を求めワイブル・パラメータの形状母数 $\mathrm{m}$, 尺度母数 $\xi$, 平均值 $\mu$, 標準偏差（分散 $V$ の平方根）走求めた。 得られた結果を Table III示す。供試モルタルの衝撃引 張り強度は割裂試験による静的引張り強度に比べて約 1.5 倍で, 静的曲げ強度より若干小さな值をとることが わかる。な扎，この結果は粗骨材を含むコンクリート材 に関する実験結果と同様な傾向である。21 , 22) 試験材料に 石高，セラミックス（アルミナ，ムライト）存用いた実 験結果では, 衝撃引張り強度は静的引張り強度よりわず かに大きい值をとるが，静的曲げ強度に比べ小さな值で

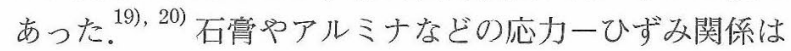
破断するまでほぼ直線関係であるのに対し，モルタル材 の元れは金属材料の塑性域に相当歹るような不完全弾性 挙動定示すこのことが供試モルタル材が石堂やセラミ

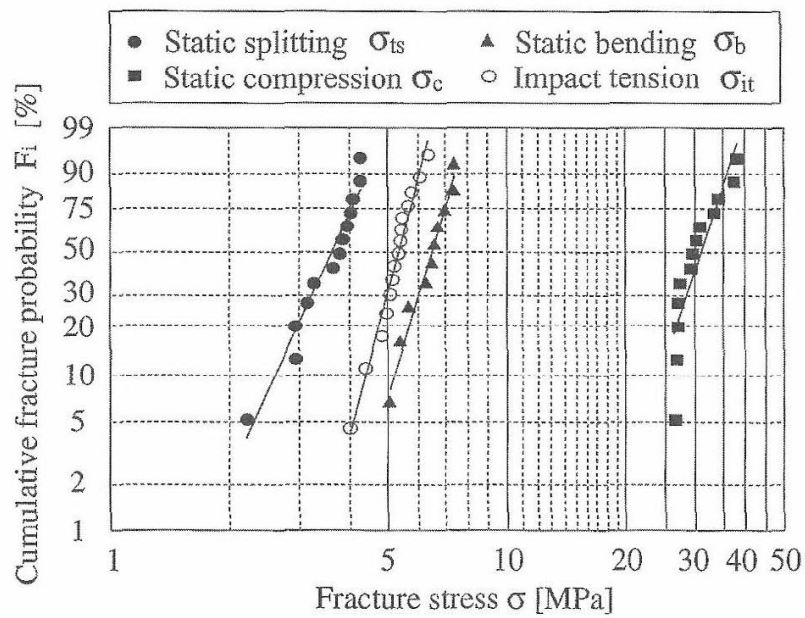

Fig. 6. Weibull distribution of mortar strengths.

Table III. Results of statistical analysis.

\begin{tabular}{|ccccc:c|c|}
\hline Test & & $\sigma_{\text {ts }}$ & $\sigma_{\mathrm{b}}$ & $\sigma_{\mathrm{c}}$ & $\sigma_{\text {it }}$ \\
\hline Number of samples $n$ & 13 & 10 & 13 & 15 \\
Shape parameter & $m$ & 5.7 & 8.7 & 8.0 & 9.6 \\
Scale parameter & $\xi$ & [MPa] & 3.8 & 6.7 & 32.4 & 5.8 \\
Mean & $\mu$ & {$[\mathrm{MPa}]$} & 3.6 & 6.4 & 30.5 & 5.5 \\
Standard deviation & s.d. & [MPa] & 0.7 & 0.9 & 4.5 & 0.7 \\
\hline
\end{tabular}

ックスに比べてより大きなひずみ速度依存性を示す要因 と考えられる。

スプリット・ホプキンソン棒法の場合は, 試験片長さ が初めから定まっており変位速度から容易にひずみ速度 が算定される。本実験においてひず速度を求める場合， 試験片中の引張り応力領域が時間とともに変化するため, 引張り応力発生捘いつの時点で破断が起こるかを，すな わち標点距離としての引張り応力領域を知る必要がある。 ここでは, 試験片上に貼られた 2 ケ所のひずみゲージの 応答から破断時間を推定しひずみ速度を算定した。

Fig. 7 は試験片に接着したひずみゲージの応答から破 断時間を推定するために用いた模式図である。 $t_{i}, t_{b}$ はそ れぞれ，引張り応力発生時間および破断開始時間であり， $t_{0}, t_{1}$ はこれらの情報がひずみゲージ位置で感知される時 間である。この測定例では, 引張り応力発生後, 破断開 始はおよそ $198 \mu \mathrm{sec}$ と推定される。すなわち標点距離と しての引張り応力領域は $l=198 \mu \mathrm{sec} \times 3571 \mathrm{~m} / \mathrm{sec}=$ $0.7 \mathrm{~m}$ となる。したがって, 粒子速度 $v$ と応力の関係 $v=$ $\sigma / \rho c$ より，ひずみ速度は $v / l=0.96 \mathrm{sec}^{-1}$ と求められる。

\section{5 応力波動の数值シミュレーション}

本実験法の 1 次元波動モデルの妥当性を検証するため， モルタル試験片棒を伝ぱする応力波の数值シミュレーシ ヨンを FEM コード (MARC) を用いて軸対称 2 次元問題 として行った.

Fig. 8 に数值計算に用いたモルタル試験片棒への入射 応力波形を示す。2 点ひずみグージ法 ${ }^{18)}$ で演算処理して 得られた入射応力を太い実線で示す。入力伝達棒上のゲ 


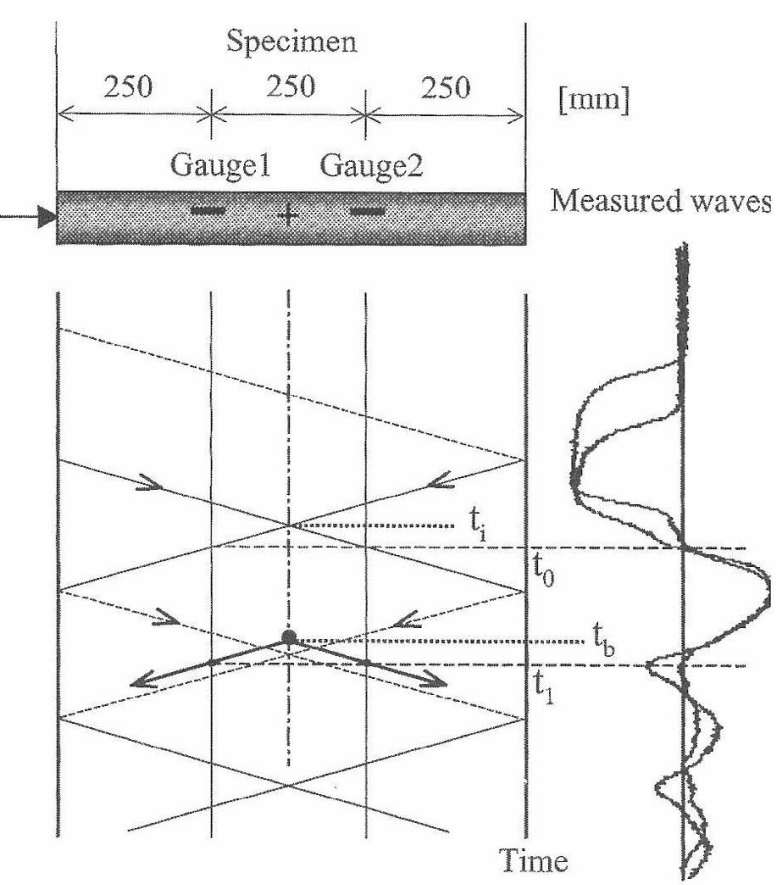

Fig. 7. Estimation of break time after initiation of tensile stress concentration.

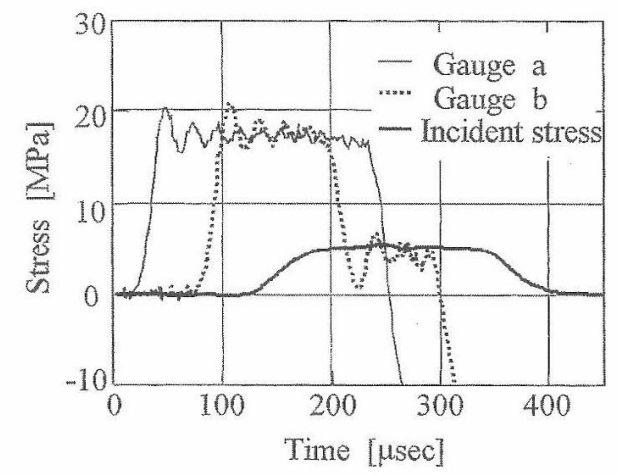

Fig. 8. Incident stress waves.

一ジ位置 $a, b$ で測定された応力波形は比較的立ち上が り時間が早く, 主として入力伝達棒の横慣性の影響によ る高周波成分の重畳が見られる。 ${ }^{24)}$ 図中の入射応力波形 はこれらの高周波成分の影響艺除いて算定した。

Fig. 9 に数値計算結果を示す. 白黒の浱淡は応力值を 示しており，白地は応力が無い状態を表している。压縮 入射応力波が伝ぱし試験片棒全体が圧縮状態になった 後, 両端からの引張り波によって打ち消され，続いてモ ルタル試験片棒の中央付近から引張り応力領域が発達し てゆくことがわかる。Fig. 5 の実験結果とよく封応して いる.

直径 $50 \mathrm{~mm}$ の入力伝達棒とモルタル試験片棒の接触端 面を完全密着させて実験を行うことは相当に困難である。 片当たりを避けるため, 入力伝撻棒の接触面にサンドペ 一パーでわずかな丸みを付けて, 衝撃初期に試験片棒端 の部に入射応力が妘達されるように実験を行った。こ の入力端面の影響を調べるため, 試験片棒の軸心部接触 面にランプ状入力が入射する場合について検討を行った。

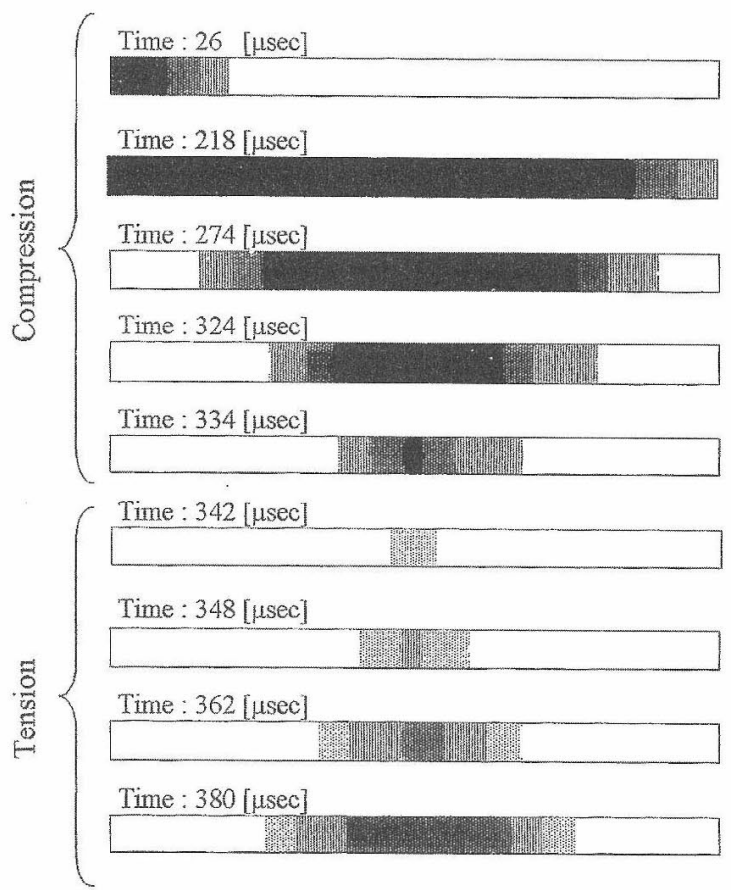

Fig. 9. Propagation of incident comprssive stress wave and development of tensile stress region.

Fig. 10 に，一例として，立上がり時間 $30 \mu \mathrm{sec}$ のラン プ入力が軸心部の直径 $20 \mathrm{~mm}$ の円形領域に入射すると仮 定した場合の計算結果示す. $T=c_{0} t / d$ は無次元時間 で, $T=1$ で応力波頭怔試験片棒直径と同じ距離に達す る。試験片棒直径の拉よ气 3 倍の位置で既に軸方向応力 がほぼ一様な状態になることがわかる。上記の衝撃引張 り実験においては, 入力伝達棒扎よび試験片棒上のひず みゲージ接着位置は衝撃端より直径の 3 倍以上として計 測を行った。また，モルタル試験片棒は直径の 15 倍の長 さのものを用いたが，Fig. 9 および Fig. 10 の結果は，さら に短い試験片棒の使用が可能であることを示している。

\section{6 結言}

本論文では 1 次元応力波の入反射・重ね合わせを利用 した反射引張り応力波法によるモルタル材の衝撃引張り 強度測定と評価法について検討を行い，次の結果を得た。

(1) モルタル試験片棒にお打引引張り応力領域の進展

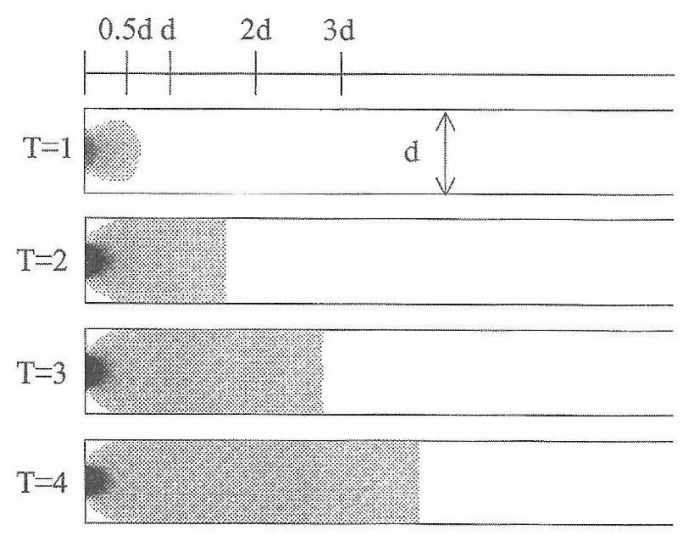

Fig. 10. Propagation of incident stress wave near the impact end of a mortar specimen. 
および試験片の破断位置は 1 次元応力波動の図式解法よ り予測される結果にほぼ一致した。

（2）供試モルタル材の静的および衝撃強度をワイブル 分布を用いて統計的に評価した。衝撃引張り強度は，ひ ずみ速度依存性を示し静的引張り強度（静的割裂強度） に比べ約 1.5 倍の值を示した．また，そのときのひずみ 速度は打よそ $10^{0} \mathrm{sec}^{-1}$ と推定された。

（3）モルタル試験片棒に関する軸対称 2 次元応力波動 の数值解析を行い本実験法の妥当性を検証した. なお， ここではモルタル試験片棒は均質等方で弾性体と仮定し て数值計算を行っており，今後，骨材を含む材料特性 を考慮した波動分散などを検討する必要があると考えて いる。

\section{参 考 文 献}

1）日本コンクリート協会編，“コンクリート便覧”（第二版） （1996）技報堂出版.

2) H. W. Reinhardt, "Cement Based Composires : Strain Rate Effects on Fracture", ed. S. Mindess and S. P. Shah, (1986) Material Research Society.

3 ) H. Kolsky, "Stress Wave in Solids" (1953) Clarendon Press.

4) W. Johnson, "Impact Strength of Materials" (1972) Edward Amord.

5) 林 卓夫, 田中吉之助, “衝撃工学”（1988）日刊工業新 聞社.

6）谷村眞治，材料・構造物の衝撃的破壊現象とその防止に関 する調查研究分科会シンポジウム講演論文集（1998）日本 機械学会.

7）野中泰二郎, 構造物の衝撃的破壊メカニズムの解明と防止, 京都大学防災研究所特定共同研究 (8P-1) 報告書 (1998).

8) 西 弘明, “PC 落石覆工の耐衝撃挙動に関する研究” (1999) 室蘭工業大学博士学位論文.
9 ）園田恵一郎，第 4 回構造物の衝撃問題に関するシンポジウ 么論文集, p.257 (1998).

10) 土木学会コンクリート委員会, コンクリート標準示方書 (1999）土木学会.

11) C. A. Ross, S. T. Kuennen and J. W. Tedesco, Micromechanics of Failure of Quasi-Brittle Materials, 353 (1990).

12) J. Weerheijm and H.W. Reinhardt, Nuclear Engineering and Design, 126, 395 (1991).

13) C. Albertini, E. Cadoni and K. Labibes, Journal de Physique IV, 7, C3-915 (1997).

14）實 晃司, 白井孝治, 伊藤千浩, 大沼博志, 土木学会構 造工学委員会, 第 4 回構造物の衝撃問題に関するシンポジ ウム論文集，119（1998）。

15）横山 隆，材料試験技術，43，221（1998）.

16) T. Nicholas, Experimental Mechanics, 21, 177 (1981).

17) T. Nojima and K. Ogawa, Journal De Physique, Colloque C5, 46, 623 (1985).

18) M. Daimaruya, H. Kobayashi and S. Bustami, DYMAT Journal, 1, 289 (1994).

19) M. Daimaruya, H. Kobayashi, S. Bustami and M.Chiba, J. Japanese Soci. Strength and Fracture of Materials, 30, 1 (1996).

20）臺丸谷政志，小林秀敏，ブスタミ・シャム，千葉光弘，材 料, 45, 823 (1996).

21) M. Daimaruya, H. Kobayashi and T. Nonaka, Journal de Physique IV, 7, C3-253 (1997).

22）臺丸谷政志, 小林秀敏, 千葉光弘, 前田裕生, 日本機械 学会論文集，A-63，2592（1997）.

23）西田俊彦, 安田榮一, “セラミックスの力学的特性評価” （1986）日刊工業新聞社.

24）内藤正鄰，臺丸谷政志，日本機械学会論文集，A-50, 1097 (1984). 